\title{
PEMANFAATAN LIMBAH FLY ASH DAN BOTTOM ASH DARI PLTU SUMSEL-5 SEBAGAI BAHAN UTAMA PEMBUATAN PAVING BLOCK
}

\author{
Hadi Winarno', Damris Muhammad², Rayandra Ashyar ${ }^{3}$, Yudha Gusti Wibowo 4 \\ Program Studi Ilmu Lingkungan, Universitas Jambi \\ Jln. A Manaf Telanaipura Jambi 36124 \\ +6281373645090 \\ Tumpangsari14@gmail.com
}

\begin{abstract}
Fly ash and bottom ash are solid waste from coal combustion in the operating system of Steam Power Plant (PLTU). The research was conducted by combining fly ash and bottom ash with an adhesive consisting of portland cement. Based on the tests performed the maximum mixture obtained with cement samples, fly ash and bottom ash is 1: 2: 2. Paving blocks made from fly ash and bottom ash have compressive strength values resulting in compressive strength values of $50.52 \mathrm{MPa}$. This value indicates that the sample is in the class of paving blocks A. Paving Block made from fly ash and bottom ash also has a very good average air absorption value, in a combination of suitable cement mixtures, fly ash and bottom ash (1:2:2) the average air absorption value is still $5.06 \%$. This value shows that the sample is in class B paving blocks.
\end{abstract}

Keyword : Fly Ash, Bottom Ash, Cement, Paving Block

\section{PENDAHULUAN}

Coal Fire Steam Power Plant (CSFPP) adalah model Pembangkit Listrik Tenaga Uap (PLTU) yang mengolah air demineral menjadi uap air kering (saturated steam) untuk memutar turbine dan membangkitkan generator berkapasitas tertentu. Dimana air dimasak dalam bejana yang disebut steam drum dan dipanaskan dalam tungku pemanas (furnace) yang berbahan bakar batubara sebagai bahan bakar utamanya. Sistem pemanasan ini didunia ketehnikan disebut sebagai boiler. Boiler CFB di PLTU Sumsel-5 berkapasitas produksi steam
580 ton/jam untuk membangkitkan tubin berkapasitas 175 MW dipasang berganda. Dengan kapasitas ini, sistem ini mengkonsumsi batubara sebanyak 144 ton/jam untuk setiap unitnya. Dari konsumsi batubara tersebut menghasilkan limbah padat yang berupa bottom ash sebanyak 2 ton/jam dan fly ash 8 ton/jam.

Berikut ini adalah volume limbah padat yang dihasilkan dari proses pembakaran dalam sistem CFB Boiler yang dimiliki oleh PLTU Sumsel-5:

Tabel 1. Table Volume ash yang dihasilkan dari PLTU Sumsel-5 (2x130 MW)

\begin{tabular}{|c|c|c|c|c|c|c|}
\hline $\begin{array}{r}\text { Ash } \\
\text { Volume }\end{array}$ & \multicolumn{2}{|c|}{$\begin{array}{c}\text { Hourly ash volume } \\
(t / h)\end{array}$} & \multicolumn{2}{|c|}{$\begin{array}{c}\text { Daily ash } \\
\text { discharge }(t / d)\end{array}$} & \multicolumn{2}{|c|}{$\begin{array}{c}\text { Annual ash discharge } \\
\left(10^{4} / a\right)\end{array}$} \\
\hline Item & $\begin{array}{l}\text { Desige } \\
n \text { Coal }\end{array}$ & $\begin{array}{l}\text { Worst } \\
\text { Coal }\end{array}$ & $\begin{array}{l}\text { Design } \\
\text { Coal }\end{array}$ & $\begin{array}{l}\text { Wors } \\
\text { Coal } \\
\end{array}$ & $\begin{array}{l}\text { Desig } \\
n \text { Coal } \\
\end{array}$ & Worst Coal \\
\hline $\begin{array}{cc}\text { Fly } & \text { Ash } \\
\text { Volume } & \\
\end{array}$ & 8,34 & 22,74 & 200,16 & $\begin{array}{l}545,7 \\
6 \\
\end{array}$ & 5,846 & 15,938 \\
\hline $\begin{array}{r}\text { Bottom } \\
\text { ash volume }\end{array}$ & 2,09 & 5,68 & 50,16 & $\begin{array}{l}136,3 \\
2\end{array}$ & 1,465 & 3,981 \\
\hline $\begin{array}{l}\text { Total Ash } \\
\text { volume }\end{array}$ & 10,43 & 28,42 & 250,32 & $\begin{array}{l}682,0 \\
8\end{array}$ & 7,311 & 19,92 \\
\hline
\end{tabular}

Sumber : China National Electric Engineering Mine Mouth CFSPP SUMSEL-5 (2014:8)

Proses tersebut dapat terjadi karena sistem pembakaran yang baik dari desain sistem pada furnace. Dalam sistem pembakaran tersebut $\mathrm{CFB}$ Boiler menggunakan batubara sebagai umpan utamanya. Dari proses pembakaran batubara inilah terbentuk limbah padat yang berupa fly ash dan bottom ash.

Menurut Misbachul, (2008:12) fly ash adalah abu batubara yang sangat halus yang berasal dari aktifitas pembakaran batubara didalam furnace dari suatu boiler pembangkit. Fly Ash banyak mengandung mineral yang mengandung mineral anorganik seperti $\mathrm{SiO}_{2}, \mathrm{Al}_{2} \mathrm{O}_{3}, \mathrm{P}_{2} \mathrm{O}_{5}$ dan $\mathrm{Fe}_{2} \mathrm{O}_{3}$ yang dapat mencemari lingkungan, seperti pencemaran udara dan pencemaran tanah.

Bottom Ash adalah abu yang terbentuk dari proses pembakaran didalam furnace yang berupa padatan yang tidak terbawa oleh flue gas. Dalam 
sistem CFB, botoom ash adalah campuran antara abu batubara, pasir kuarsa dan pecahan-pecahan diding furnace yang terkikis selama proses pembakaran berlangsug.

Volume yang sangat banyak juga menimbulkan masalah baru, karena membutuhkan banyak ruang uantuk menampungnya. Butuh tempat yang sangat luas untuk tempat penimbunan abu. Abu tersebut perlu dimanfaatkan kembali menjadi bahan yang berguna sehingga volume abu dapat berkurang. Diperlukan inovasi untuk memberi nilai tambah (add value) abu ini menjadi bahan yang bisa dimanfaatkan kembali baik sebagai bahan utama ataupun bahan campuran bahan-bahan bangunan.

Pemanfaatan fly ash telah banyak dilakukan, diantaranya adalah pemanfaatan sebagai bahan pengganti agregad dalam produksi paving block. Menurut Mulyanti (2006:1), fly ash telah diaplikasikan sebagai pengganti agregad dalam produksi paving block. Dalam penelitian tersebut fly ash dipadukan dengan batu split dengan portland cement sebagai perekatnya. Hasil penelitian menyebutkan fly ash dapat ditambahkan sampai dengan 50\% dengan hasil kuat tekan mencapai $262,82 \mathrm{~kg} / \mathrm{cm}^{2}$. Kondisi optimum didapatkan pada penggunaan $30 \%$ fly ash dengan nilai kuat tekan sampai $335 \mathrm{~kg} / \mathrm{cm}^{2}$.

Menurut Sebayang, Surya (2006:117), Fly ash memiliki karakter partikel yang lebih halus dibanding semen Portland dan memiliki sifat hidrolik. Karakteristik ini sangat memungkinkan fly ash digunakan sebagai salah satu bahan pengganti semen dalam pembuatan beton bermutu tinggi.

Menurut Suseno, Hendro (2012:272) bottom ash banyak digunakan sebagai bahan pembuatan bata, karena kandungan silica didalamnya. Bottom ash memiliki kesamaan karakteristik seperti tanah liat. Persentase campuran bottom ash maksimun untuk pembuatan bata yang baik adalah $45 \%$.

Dalam penelitian ini penulis ingin mencoba lebih memaksimalkan dalam menambahkan kadar limbah fly ash dan bottom ash. Hal ini sangat memungkinkan bila kita mengetahui karakteristik limbah fly ash dan bottom ash ini. Selain itu penulis juga akan menambah parameter serapan air rata-rata sebagai parameter penunjang untuk memastikan kualitas produk paving block yang dihasilkan.

Demikiah penulis melihat potensi pemanfaatan fly ash dan bottom ash sebagai bahan pembuatan paving block dengan memadukan semen sebagai bahan perekatnya. Paving block ini adalah salah satu jenis dari bata ringan yang banyak diperlukan untuk kebutuhan kontruksi. Penelitian ini perlu dilakukan guna mencari solusi untuk mengurangi beban pencemaran lingkungan secaralangsung akibat penimbunan limbah padat yang berupa bottom ash dan fly ash dari aktivitas operasi PLTU Sumsel-5.

\section{METODE}

Penelitian dilakukan selama bulan Februari sampai dengan bulan Juli 2017. Penelitian dilakukan dibeberapa tempat yang berbeda sesuai dengan kebutuhan yang diperlukan peneliti. Untuk pengambilan sampel dilakukan di site PLTU Sumsel-5, didesa Sindang Marga, Kecamatan Bayung Lencir, Kabupaten Musi Banyuasin Sumatra Selatan. 1) Proses produksi dilakukan di Workshop UKM Mulio Asih, Suka Jaya, desa Suka Jaya, Kecamatan Bayung Lencir, Kabupaten Musi Banyuasin Sumatra Selatan. 2) Uji kuat tekan dilakukan dilaboratorium Balai Pengijian Dinas Pekerjaan Umum dan Perumahan Rakyat Provinsi Jambi. 3) Untuk uji serapan air rata-rata dilakukan di Laboratorium Teknik Sipil, Universitas Batanghari, Jambi. 4) Untuk Scanning Electron Microscope (SEM-EDX) pada sampel terpilih pengujian dilakukan Laboratorium Inovasi dan Teknologi, Universitas Lampung.

Data penelitian ini terdiri dari 2 jenis data, yaitu : Data primer yaitu data pengujian parameter kualitas paving block yang dilakukan dilaboratorium. Adapun uji kualitas yang dilakukan adalah uji kuat tekan dan uji serapan air rata-rata yang dilakukan sesuai prosedur yang ditentukan dalam SNI 03-0691-1996. Data sekunder diperoleh dari uji pendahuluan dan studi literatur dari penelitian-penelitian sebelumnya. Data diperoleh dari buku dan jurnal dari penelitian-penelitian sejenis.

Penelitian dilakukan dengan membuat paving block yang setiap percobaan menggunakan perekat yang berupa cement portland sebanyak 2 liter atau kelipatannya. Dalam penelitian ini menggunakan rancangan faktorial (4x4). Adapun faktor yang akan diteliti adalah fly ash dan bottom ash yang dengan notasi sebagai berikut :

$$
\mathrm{F}=\text { Fly Ash }
$$

Dengan tarap yang digunakan ;

$$
\begin{aligned}
& \text { 1) } \mathrm{F} 1 \quad=1 \text { liter } \\
& \text { 2) } \mathrm{F} 2 \quad=2 \text { liter } \\
& \text { 3) } \mathrm{F} 3 \quad=3 \text { liter } \\
& \text { 4) } \mathrm{F} 4 \quad=4 \text { liter } \\
& \mathrm{B}=\text { Bottom Ash } \\
& \text { dengan tarap yang digunakan ; }
\end{aligned}
$$

1) $\mathrm{B} 1=1$ liter

5) $\mathrm{B} 2=2$ liter

6) $\mathrm{B} 3=3$ liter

7) $\mathrm{B} 4=4$ liter

Kombinasi perlakuan dari masing-masing faktor dan taraf perlakuan bila disusun dalam sebuah tabel adalah sebagai berikut : 
Tabel 2. Rancangan Faktorial Sampel (4x4)

\begin{tabular}{cccccc} 
& \multicolumn{7}{c}{ Bottom Ash } \\
\cline { 2 - 6 } Fly Ash & $\mathbf{1}$ & $\mathbf{2}$ & $\mathbf{3}$ & $\mathbf{4}$ \\
\cline { 2 - 6 } & $\mathbf{1}$ & $\mathrm{F}_{1} \mathrm{~B}_{1}$ & $\mathrm{~F}_{1} \mathrm{~B}_{2}$ & $\mathrm{~F}_{1} \mathrm{~B}_{3}$ & $\mathrm{~F}_{1} \mathrm{~B}_{4}$ \\
\cline { 2 - 7 } & $\mathrm{F}_{2} \mathrm{~B}_{1}$ & $\mathrm{~F}_{2} \mathrm{~B}_{2}$ & $\mathrm{~F}_{2} \mathrm{~B}_{3}$ & $\mathrm{~F}_{2} \mathrm{~B}_{4}$ \\
\hline & $\mathbf{2}$ & $\mathrm{F}_{3} \mathrm{~B}_{1}$ & $\mathrm{~F}_{3} \mathrm{~B}_{2}$ & $\mathrm{~F}_{3} \mathrm{~B}_{3}$ & $\mathrm{~F}_{3} \mathrm{~B}_{4}$ \\
\hline $\mathbf{3}$ & $\mathrm{F}_{4} \mathrm{~B}_{1}$ & $\mathrm{~F}_{4} \mathrm{~B}_{2}$ & $\mathrm{~F}_{4} \mathrm{~B}_{3}$ & $\mathrm{~F}_{4} \mathrm{~B}_{4}$
\end{tabular}

Keterangan : Cement dijaga konstan dengan rasio diatas, yaitu sebanyak 2 liter atau kelipatannya.

Pengujian dilaboratorium dilakukan setelah proses pengeringan selama kurang lebih 28 hari sesuai standar pengeringan dalam faktor koreksi umur beton Pengeringan dilkukan dengan proses diangin-anginkan diruang terbuka.

Parameter yang diukur dalam penelitian ini adalah mengacu pada parameter sesuai yang disyaratkan dalam SNI 03-0691-1996. Adapun parameter tersebut adalah sebagai berikut : 1) Kuat Tekan, Parameter ini berfungsi untuk mengetahui sifat fisika benda terhadap ketahanan dalam menahan beban. Satuan pengukuran diukur dalam satuan Mega Pascal (MPa), dengan prosedur pengujian terlampir. 2) Penyerapan Air Rata-rata, Semakin banyak air yang terserap oleh benda uji menunjukkan nilai kerapatan benda semakin rendah.
Sebagai parameter pendukung, terhadap sampel yang terpilih akan dibandingkan dengan sampel paving block konvensional dengan melakukan uji foto permukaan melakukan Scanning Electron Microscope (SEM) untuk melihat profil permukaan sampel. Sealain itu juga dilakukan pengidentifikasian unsur-unsur kiniawi yang ada didalamnyam dengan melakukan penyinaran menggunakan X-Ray Difractometer (XRD). Untuk melihat ketahanan produk terhadap paparan air hujan penulis juga melakukan uji keasaman $(\mathrm{pH})$, counductivity, dan turbidity.

Data hasil penelitian dianalisis dengan analisa statistik sidik ragam (Anova/Analisis of varian) pada taraf $5 \%$. Adapun tabel sidik ragam yang akan digunakan adalah sebagai berikut.

Tabel 3. Daftar Analisis Keragaman Rancangan Faktorial

\begin{tabular}{|c|c|c|c|c|c|}
\hline \multirow[t]{2}{*}{$\begin{array}{c}\text { Sumber } \\
\text { Keragaman } \\
\text { (SK) }\end{array}$} & \multirow[t]{2}{*}{$\begin{array}{c}\text { Derajat Bebas } \\
\text { (db) }\end{array}$} & \multirow[t]{2}{*}{$\begin{array}{c}\text { Jumlah } \\
\text { Kuadrat } \\
\text { (JK) }\end{array}$} & \multirow[t]{2}{*}{$\begin{array}{c}\text { Jumlah } \\
\text { Kuadrat } \\
\text { Tengah }\end{array}$} & \multirow[t]{2}{*}{$\mathbf{F}_{\text {hitung }}$} & $F_{\text {tabel }}$ \\
\hline & & & & & $5 \%$ \\
\hline Perlakuan & $\mathrm{V}_{1}=(\mathrm{n} . \mathrm{t}-1)$ & JKP & $\mathrm{JKP} / \mathrm{V}_{1}$ & KTP/KTG & $\left(\mathrm{V}_{1}, \mathrm{~V}_{5}\right)$ \\
\hline $\begin{array}{c}\text { Faktor } \\
\text { Fly Ash }\end{array}$ & $\mathrm{V}_{2}=\mathrm{n}-1$ & JKFFA & JKG/ $V_{2}$ & KTGKTG & $\left(\mathrm{V}_{2}, \mathrm{~V}_{5}\right)$ \\
\hline $\begin{array}{c}\text { Faktor } \\
\text { Bottom Ash }\end{array}$ & $\mathrm{V}_{3}=\mathrm{t}-1$ & JKFBA & $\mathrm{JKS} / \mathrm{V}_{3}$ & KTS/KTG & $\left(V_{3}, V_{5}\right)$ \\
\hline Interaksi (FxB) & $\mathrm{V}_{4}=(\mathrm{n}-1)(\mathrm{t}-1)$ & JKNT & $\mathrm{JKNT} / \mathrm{V}_{4}$ & KTGS/KTG & $\left(\mathrm{V}_{4}, \mathrm{~V}_{5}\right)$ \\
\hline Galat & $\mathrm{V}_{5}=\mathrm{V}_{6}-\mathrm{V}_{1}$ & JKG & $\mathrm{JKG} / \mathrm{V}_{5}$ & & \\
\hline Total & $\mathrm{V}_{6}=$ (n.t.r) -1 & JKTotal & JKTotal/ & & \\
\hline
\end{tabular}

Sumber : Gomez dan Gomez (1995:75).

Bila hasil analisis keragaman menunjukkan bahwa $F_{\text {hitung }}$ lebih besar daripada $F_{\text {tabel }}$ dilanjutkan dengan uji Beda Jarak Nyata Duncan (BJND) untuk mengetahui beda rerata yang ada dalam setiap percobaan.

BJND $=\mathbf{P}_{\alpha(p . v)} \cdot \mathbf{S}_{\mathbf{y}}$ ...(1)

Dengan Sy diperoleh dengan rumus :

$$
S y_{T}=\sqrt{\frac{K T G}{1 x r}} \Longleftrightarrow \text { untuk perlakuan waktu }
$$

penyimpanan

$$
\operatorname{Sy}_{N T}=\sqrt{\frac{K T G}{r}} \rightleftarrows \text { untuk interaksi }
$$

\section{PEMBAHASAN}

Dari proses produksi yang telah dilakukan, dapat di ketahui bahwa secara fisik partikel fly ash dan bottom ash memiliki kesamaan dengan pasir sungai pada umumnya. Dlihat dari fisik produk, paving block ini tidak jauh berbeda dengan paving block yang terbuat dari pasir sungai, terutama dari warna dan kekerasannya. Namun untuk lebih jauh mengetahui kualitas paving block perlu dilakukan uji dilaboratorium.Dengan memanfaatkan fly ash dan 
bottom ash sebagai bahan dalam pembuatan paving block, berarti limah padat yang sebelumnya terurai akan diisolasi dalam bentuk sebuah produk beton. Beton akan bertahan dalam waktu yang sangat lama setelah diaplikasikan. Produk beton ini juga tahan terhadap paparan sinar matahari dan air hujan dalam jangka waktu bertahun-tahun. Untuk itu perlu dilakukan uji kuat tekan dan uji serapan air rata-rata sebagai perameter penting untuk menguji kualitas produk paving block. Berikut ini adalah hasil produksi paving block dengan presentase perbandingan perekat dan jumlah limbah yang ditambahkan dengan hasil uji kualitas ujinkuat tekan dan duji serapan air rata-rata :

Tabel 4. Variasi Sampel dengan Hasil Uji Kuat Tekan Dan Serapan Air Rata-rata.

\begin{tabular}{|c|c|c|c|c|c|c|c|}
\hline \multirow{2}{*}{ No } & \multicolumn{3}{|c|}{$\begin{array}{c}\text { Satuan } \\
\text { Sampel Uji } \\
\end{array}$} & \multicolumn{2}{|c|}{$\begin{array}{l}\text { Perbandingan } \\
\text { Material }\end{array}$} & \multirow{2}{*}{$\begin{array}{l}\text { Rerata Uji } \\
\text { Kuat Tekan } \\
(\mathrm{MPa})\end{array}$} & \multirow{2}{*}{$\begin{array}{l}\text { Rerata Uji } \\
\text { Serapan Air } \\
\text { Rata-rata }(\%)\end{array}$} \\
\hline & C & $\mathbf{F}$ & B & Perekat(\%) & $\operatorname{Limbah}(\%)$ & & \\
\hline 1 & 2 & 1 & 1 & 50,0 & 50,0 & 74,53 & 7,53 \\
\hline 2 & 2 & 1 & 2 & 40,0 & 60,0 & 76,98 & 6,27 \\
\hline 3 & 2 & 1 & 3 & 33,3 & 66,7 & 73,90 & 5,73 \\
\hline 4 & 2 & 1 & 4 & 28,6 & 71,4 & 77,00 & 5,54 \\
\hline 5 & 2 & 2 & 1 & 40,0 & 60,0 & 58,16 & 6,30 \\
\hline 6 & 2 & 2 & 2 & 33,3 & 66,7 & 76,94 & 5,80 \\
\hline 7 & 2 & 2 & 3 & 28,6 & 71,4 & 75,98 & 5,42 \\
\hline 8 & 2 & 2 & 4 & 25,0 & 75,0 & 55,06 & 5,14 \\
\hline 9 & 2 & 3 & 1 & 33,3 & 66,7 & 65,13 & 6,90 \\
\hline 10 & 2 & 3 & 2 & 28,6 & 71,4 & 62,81 & 6,40 \\
\hline 11 & 2 & 3 & 3 & 25,0 & 75,0 & 59,06 & 6,31 \\
\hline 12 & 2 & 3 & 4 & 22,2 & 77,8 & 56,16 & 5,86 \\
\hline 13 & 2 & 4 & 1 & 28,6 & 71,4 & 77,31 & 5,75 \\
\hline 14 & 2 & 4 & 2 & 25,0 & 75,0 & 49,69 & 5,16 \\
\hline 15 & 2 & 4 & 3 & 22,2 & 77,8 & 56,58 & 5,30 \\
\hline 16 & 2 & 4 & 4 & 20,0 & 80,0 & 50,39 & 5,07 \\
\hline
\end{tabular}

Dari setiap sampel menunjukkan perbandingan antara perekat dan limbah yang dapat diisolasi. Dari sampel pertama menunjukkan perbandingan sampel dimulai dari percobaan untuk memadukan perekat dengan limbah dengan perbandingan 50\% : 50\%. Hasil rata-rata untuk uji kuat teannya $74,53 \mathrm{MPa}$. Nilai ini sangat tinggi karena untuk paving block kelas A batas minimumnya adalah $40 \mathrm{MPa}$ Sedangkan untuk serapan air rata-rata adalah sebesar $7,53 \%$. Kemudian pada variasi berikutnya penulis mencoba menambahkan kadar limbah sampai dengan $60 \%$, 70\% dan 80\%. Sampai pada limbah ditambahkan secara maksimum dengan paduan perekat berbanding fly ash dan bottom ash (1:2:2) yang diwakili oleh sampel $\mathrm{F}_{4} \mathrm{~B}_{4}$.

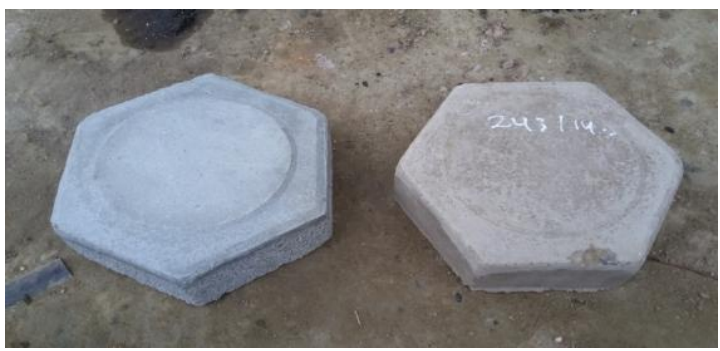

Secara umum paving block berbahan fly ash dan bottom ash adalah sama, baik dari teknis pembuatannya dan bentuk produk yang dihasilkan. Hanya saja pada produksi paving bock konvensional yang menggunakan material pasir dari sungai, di subsitusikan dengan material serupa yaitu fly ash dan bottom ash. Hasil uji menunjukkan bahwa sampel paving block berbahan fly ash dan bottom ash memiliki kualitas yang lebih baik, sebagaimana dapat dilihat pada Tabel 4. Berikut adalah gambar yang menunjukkan perbedaan antara paving block konvensional dengan paving block berbahan fly ash dan bottom ash. 


\section{Gambar 1. Perbandingan Paving block konvensional dengan Paving block berbahan limbah fly ash dan bottom ash dilihat dari bagian luar (kiri) dan bagian dalamnya (kanan).}

Pada gambar diatas terlihat paving block konvensional terlihat berwarna abu-abu (kiri). Sedangkan paving block berbahan limbah berwarna kecoklat-coklatan (kanan). Angka nilai uji kuat tekan sample paving block konvensional berada dikisaran $20 \mathrm{MPa}$. Hasil tersebut sangat jauh berbeda bila kita bandingkan dengan sampel paving block berbahan fly ash dan bottom ash (tabel 4.2).

Setelah sampel di kupas menggunakan gerinda, didapatlah gambar kerapatan susunan partikel. Berikut adalah gambar bentuk susunan komponen material dilihat secara kasat mata. Gambar diatas menunjukkan paving block konvensional memiliki pori-pori yang lebih besar. Kondisi ini membuat air lebih banyak terserap dan ikatan antar partikel tidak terlalu kuat. Selain itu komponen agregad terlihat homogen dengan ukuran partikel yang beraturan sama besar.

Sedangkan paving block yang terbuat dari fly ash dan bottom ash memiliki tekstur yang lebih rapat dan air tidak mudah masuk kedalam pori-pori paving block. Selain itu ukuran partkel terkombinasi dengan baik antara partikel halus dengan beberapa batu batuan yang ukurannya lebih besar membentuk susunan yang solid.

Dengan memanfaatkan Fly Ash dan Bottom Ash sebagai bahan dasar dalam pembuatan paving block maka kita berarti melakukan upaya-upaya perlindungan terhadap pencemaran lingkungan, khususnya disekitar lingkungan site PLTU Sumsel5. Berikut ini keuntungan bila kita dapat memanfaatkan fly ash dan bottom ash sebagai bahan dasar dalam pembuatan paving block:

1) Mengurangi penyebaran partikulat pencemar dilingkungan site PLTU Sumsel-5.

2) Mengurangi kegiatan eksplorasi pasir sungai dengan mengurangi kebutuhan penggunaan pasir.

3) Dapat megurangi kemungkinan konflik masyarakat terhadap pencemaran area pemukiman.

4) Dapat dijadikan program CSR pihak perusahan untuk pembangunan jalanndan sekolah dan fasilitas umum laindengan produk olahan fly ash dan bottom ash.

5) Membantu pengusaha/UKM produsen paving block dengan menurunkan biaya produksi.

6) Memberikan keterampilan dalam membuat paving block bagi masyarakat yang membutuhkan.

Paving Block adalah salah satu produk bata beton. Menurut SNI 03-0691-1989, Paving Block adalah suatu komposisi bahan bangunan yang dibuat dari campura perekat hidrolisis atau semen portland dan agregad (SNI 1996 : 5). Dalam menelitian ini penulis menggunakan Portlind Composite Cement
(PPC) sebagai perekatnya, fly ash dan bottom ash sebagai gregadnya. Fly ash berfungsi sebagai bahan subsitusi agregad halus dan bottom ash sebagai subsitusi agregad kasarnya.

Dalam penelitian ini dilakukan 16 macam perlakuan. Perlakuan pertama memadukan 50\% Perekat dan 50 limbah. Selanjutnya kadar limbah ditambah dalam setiap varian perlakuan berikutnya. Sampai perbandingan perekat dan limban sebanyak $20 \%$ perekat dan $80 \%$ limbah. Pelakuan ini di maksudkan untuk mencari titik optimum penambahan material limbah dengan tetap menjaga kualitas kuat tekan paving block yang dihasilkan.

Perlakuan yang diberikan pada sampel paving block memberikan pengaruh yang nyata terhadap produk yang dihasilkan. Hal tersebut ditunjukkan dengan nilai $F_{\text {hitung }}$ yang lebih besar dari $F_{\text {tabel }}$. Yangmana nilai $F_{\text {hitung }}$ untuk perlakuan adalah 5.424,9983 sedangkan $F_{\text {tabel }}$ adalah 3,3. Hasil ini menunjukkan setiap variasi paduan pada masingmasing sampel sangat beragam.

Dari data yang diperolah dalam pengujian uji kuat tekan, terlihat faktor nilai $F_{\text {hitung }}$ yang lebih besar dari $\mathrm{F}_{\text {tabel }}$. Yangmana nilai $\mathrm{F}_{\text {hitung }}$ untuk faktor Fly Ash adalah 11.518,98 sedangkan $\mathrm{F}_{\text {tabel }}$ adalah 2,9. Hasil ini menunjukkan setiap variasi paduan pada masing-masing sampel berbeda. Demikian pula untuk faktor bottom ash, dalam setiap variasi perlakuan jumlahnya. Jumlah minimum yang ditambahka adalah $10 \%$ dan jumlah maksimumnya adalah $40 \%$ dari berat bahan baku. Hasilnya dalam setiap pengujian menunjukkan adanya perbedaan. Dari data yang diperolah dalam pengujian uji kuat tekan, terlihat faktor nilai $F_{\text {hitung }}$ yang lebih besar dari $\mathrm{F}_{\text {tabel }}$. Yangmana nilai $\mathrm{F}_{\text {hitung }}$ untuk Faktor Bottom Ash adalah 3.092,8295 sedangkan $\mathrm{F}_{\text {tabel }}$ adalah 2,9. Aangka ini lebih rendah bila dibanding beda jarak faktor fly ash. Artinya karakteristik bottom ash tidak sebanyak fly ash dalam memberikan pengaruh terhadap kualias kuat tekan sampel.

Interaksi fly ash dan bottom ash pada sampel paving block memberikan pengaruh yang nyata terhadap produk yang dihasilkan. Hal tersebut ditunjukkan dengan nilai $\mathrm{F}_{\text {hitung }}$ yang lebih besar dari $F_{\text {tabel }}$. Yangmana nilai $F_{\text {hitung untuk interksi }}$ perlaakuan adalah 4.171,0588 sedangkan $F_{\text {tabel }}$ adalah 2,19. Hasil ini menunjukkan setiap variasi paduan pada masing-masing sampel beragam. Karena hasil analisis keragaman menunjukkan bahwa $F_{\text {hitung }}$ lebih besar daripada $F_{\text {tabel }}$ dilanjutkan dengan uji Beda Jarak Nyata Duncan (BJND) untuk mengetahui beda rerata yang ada dalam setiap percobaan. Berikut ini adalah hasil uji kuat tekan pada sampel paving block dilihat dari beda jarak nyatanya. 
Tabel 5. Tabel Hasil Uji Beda Jarak Nyata Duncant (BJND)

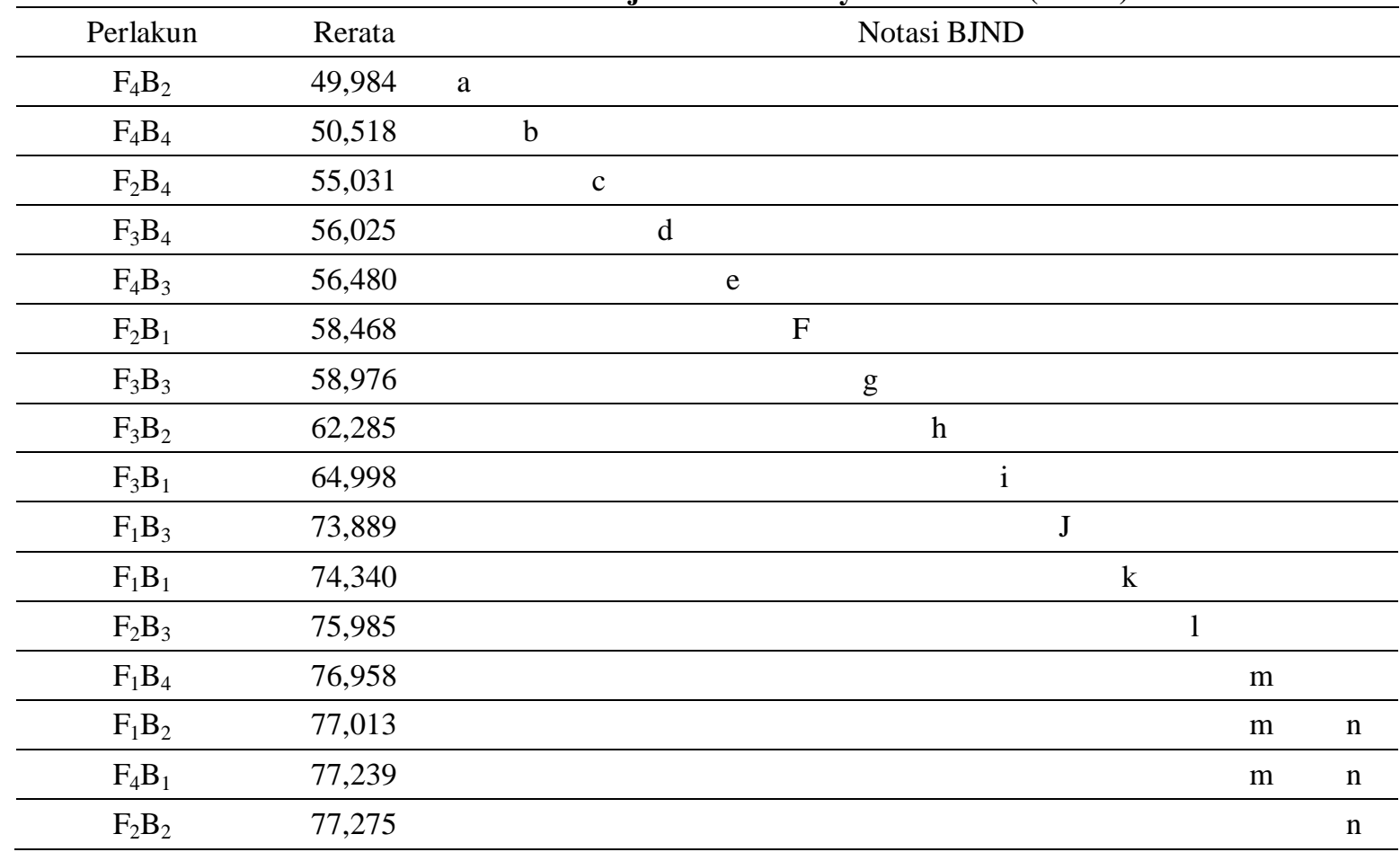

Dari Tabel 5 terihat bahwa pengaruh penambahan fly ash dan bottom ash terbaik diperoleh pada perlakuan $\mathrm{F}_{4} \mathrm{~B}_{4}$, karena pengaruh penambahan fly ash dan botto ash ini berbeda nyata dan/atau sangat nyata dengan pengaruh lebih sempit dan semua berbeda nyata. Dari 16 perlakuan yang telah dilakukan, juga terdapat beda jarak yang tidak nyata yaitu pada perlakuan $\mathrm{F}_{1} \mathrm{~B}_{2}$ dan $\mathrm{F}_{4} \mathrm{~B}_{1}$. Terkait dengan standar kualitas yang ditentukan BSN dalam SNI 03-0691-1996, hasil uji kuat tekan dalam setiap perlakuan dapat dilihat dalam grafik berikut ini :

Hasil Uji Kuat Tekan (MPa)

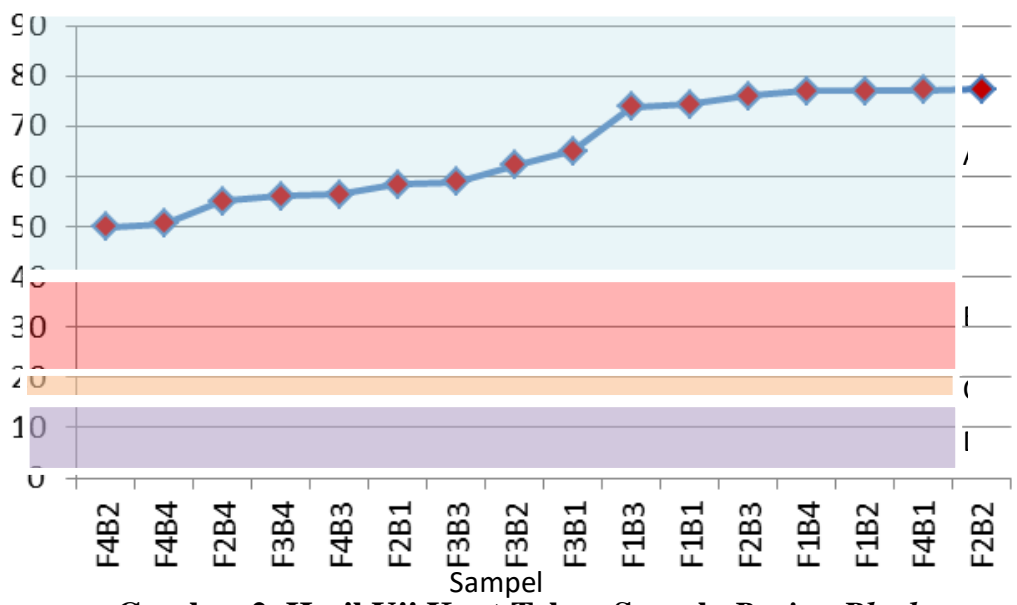

Gambar 2. Hasil Uji Kuat Tekan Sample Paving Block.

Dari keseluruhan sampel yang diuji memberikan hasil diatas nilai kuat tekan mutu A. Sebagaimana dalam SNI 03-0691-1996 disyaratkan untuk mutu A adalah diatas $40 \mathrm{MPa}$. Sedangkan untuk paduan Maksimum untuk sampel $\mathrm{F}_{4} \mathrm{~B}_{4}$ dengan paduan $20 \%$ perekat dan $80 \%$ limbah (40\%) fly ash dan $40 \%$ bottom ash), hasilnya adalah 50,518 $\mathrm{MPa}$.

Telah dilakukan uji rerapan air rata-rata dengan 3 kali pengulangan. Besarnya pengaruh fly ash dan bottom ash dalam dalam mempengaruhi kualitas serapan air rata-rata. Dari uji yang telah dilakukan terlihat perlakuan yang diberikan pada sampel paving block memberikan pengaruh yang nyata terhadap hasil uji serapanair rata-rata. Hal tersebut ditunjukkan dengan nilai $F_{\text {hitung }}$ yang lebih besar dari $F_{\text {tabel }}$. Yangmana nilai $F_{\text {hitung }}$ untuk perlakuan adalah 54,111352 sedangkan $F_{\text {tabel }}$ adalah 1,955. Hasil ini menunjukkan setiap variasi paduan pada masingmasing sampel sangat beragam. 
Besaran nilai yang didapatkan dalam pengujian serapan air rata-rata dipengaruhi karakteristik fly ash. Partikel fly ash yang sangat halus membuat paving block yang memiliki luas permukaannya yang lebih besar. Sehingga Paving block yang menyerap banyak air lebih lama dalam menguapkan membali. Dari data yang diperolah dalam pengujian uji serapan air rata-rata, terlihat faktor nilai $F_{\text {hitung }}$ yang lebih besar dari $\mathrm{F}_{\text {tabel }}$. Yangmana nilai $\mathrm{F}_{\text {hitung }}$ untuk Faktor Fly Ash adalah 115,69479 sedangkan $F_{\text {tabel }}$ adalah 2,9.

\section{Faktor Bottom Ash}

Dari data yang diperolah dalam pengujian uji serapan air rata-rata, terlihat faktor nilai $F_{\text {hitung }}$ yang lebih besar dari $F_{\text {tabel }}$. Yangmana nilai $F_{\text {hitung }}$ untuk Faktor Bottom Ash adalah 125,91723 sedangkan $\mathrm{F}_{\text {tabel }}$ adalah 2,9. Aangka ini lebih tinggi bila dibanding beda jarak faktor fly ash. Artinya karakteristik bottom ash tidak sebanyak fly ash dalam memberikan pengaruh terhadap kualias serapan air rata-rata sampel. Hal ini disebabkan partikel bottom ash yang lebih besar menyebapkan paving block berpori lebih besar sehingga menyerapair lebih banyak.

\section{Interaksi Perlakuan}

Interaksi fly ash dan bottom ash pada sampel paving block memberikan pengaruh yang nyata terhadap produk yang dihasilkan. Hal tersebut ditunjukkan dengan nilai $F_{\text {hitung }}$ yang lebih besar dari $F_{\text {tabel }}$. Nilai $F_{\text {hitung }}$ untuk interksi perlaakuan adalah 9,6482471 sedangkan $F_{\text {tabel }}$ adalah 2,19. Hasil ini menunjukkan setiap variasi paduan pada masingmasing sampel beragam. Namun demikian dalam uji serapan air rata-rata data menunjukkan rentang nilai beda yang lebih besar bila dibanding uji kuat tekan.

Karena hasil analisis keragaman menunjukkan bahwa $\mathrm{F}_{\text {hitung }}$ lebih besar daripada $\mathrm{F}_{\text {tabel }}$ dilanjutkan dengan uji Beda Jarak Nyata Duncan (BJND) untuk mengetahui beda rerata yang ada dalam setiap percobaan. Berikut ini adalah hasil uji serapan air rata-rata pada sampel paving block dilihat dari beda jarak nyatanya.

Tabel 6. Hasil Uji Beda Jarak Nyata Duncant (BJND) Uji Serapan Air Rata-rata

\begin{tabular}{|c|c|c|c|c|c|c|}
\hline Perlakun & Rerata & & \multicolumn{4}{|c|}{ Notasi BJND } \\
\hline $\mathrm{F}_{4} \mathrm{~B}_{4}$ & 5,066367961 & $\mathrm{a}$ & & & & \\
\hline $\mathrm{F}_{2} \mathrm{~B}_{4}$ & 5,135131006 & $\mathrm{a}$ & & & & \\
\hline $\mathrm{F}_{4} \mathrm{~B}_{2}$ & 5,16069262 & $\mathrm{a}$ & $\mathrm{b}$ & & & \\
\hline $\mathrm{F}_{4} \mathrm{~B}_{3}$ & 5,300755016 & $\mathrm{a}$ & $\mathrm{b}$ & $\mathrm{c}$ & & \\
\hline $\mathrm{F}_{2} \mathrm{~B}_{3}$ & 5,424522536 & & $\mathrm{~b}$ & $\mathrm{c}$ & & \\
\hline $\mathrm{F}_{1} \mathrm{~B}_{4}$ & 5,53579845 & & & $\mathrm{c}$ & & \\
\hline $\mathrm{F}_{1} \mathrm{~B}_{3}$ & 5,725099284 & & & $\mathrm{~d}$ & $\mathrm{e}$ & \\
\hline $\mathrm{F}_{4} \mathrm{~B}_{1}$ & 5,750023273 & & & $\mathrm{~d}$ & $\mathrm{e}$ & \\
\hline $\mathrm{F}_{2} \mathrm{~B}_{2}$ & 5,799097225 & & & $\mathrm{~d}$ & $\mathrm{e}$ & \\
\hline $\mathrm{F}_{3} \mathrm{~B}_{4}$ & 5,863011453 & & & & $\mathrm{e}$ & \\
\hline $\mathrm{F}_{1} \mathrm{~B}_{2}$ & 6,267378373 & & & & $\mathrm{f}$ & \\
\hline $\mathrm{F}_{2} \mathrm{~B}_{1}$ & 6,29563538 & & & & $\mathrm{f}$ & \\
\hline $\mathrm{F}_{3} \mathrm{~B}_{3}$ & 6,307215956 & & & & $\mathrm{f}$ & \\
\hline $\mathrm{F}_{3} \mathrm{~B}_{2}$ & 6,402227517 & & & & $\mathrm{f}$ & \\
\hline $\mathrm{F}_{3} \mathrm{~B}_{1}$ & 6,902945262 & & & & & $\mathrm{~g}$ \\
\hline $\mathrm{F}_{1} \mathrm{~B}_{1}$ & 7,52563197 & & & & & $\mathrm{~h}$ \\
\hline
\end{tabular}

Dari Table 6 terlihat bahwa pengaruh penambahan fly ash dan bottom ash terbaik diperoleh pada perlakuan $\mathrm{F}_{4} \mathrm{~B}_{4}$, karena pengaruh penambahan fly ash dan bottom ash ini berbeda nyata dan/atau sangat nyata dengan pengaruh lebih sempit dan bebeda tidaknyata dengan pengaruh lebih sempit (lampiran 11).

Hasil uji serapan air rata-rata dalam setiap perlakuan dapat dilihat dalam grafik berikut ini : 


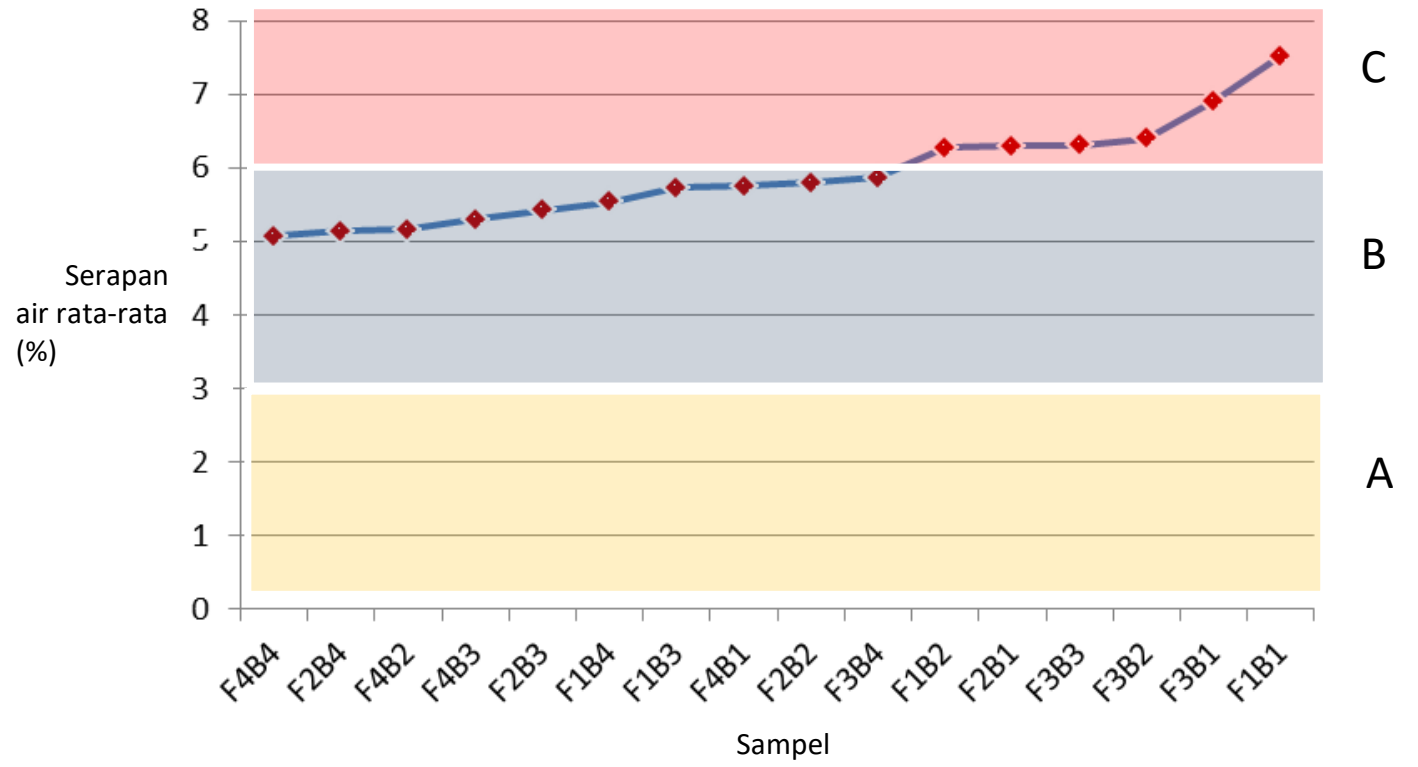

Gambar 3. Grafik Nilai Uji Serapan Air Rata-rata Paving Block

Dari hasil uji serapan air rata-rata yang dilakukan, diperoleh hasil uji masuk kedalam kelas B. Karena hasil pengujian sampel menunjukkan bahwa serapan air rata-rata sampel tertinggi di bawah $8 \%$ dan hasil terendah diatas 3\%. Hasil uji serapan air rata-rata terendah adalah sampel $\mathrm{F}_{4} \mathrm{~B}_{4}$ dengan serapan air rata-rata 5,06\%. Sedangkan hasil uji serapan air rata-rata tertinggi adalah pada sampel $\mathrm{F}_{1} \mathrm{~B}_{1}$ dengan nilai serapan air rata-rata $7,53 \%$.
Dari hasil diatas juga terlihat bahwasanya, semakin banyak penambahan volume fly ash, produk paving block semakin banyak menyerap air. Karena semakin banyak kandungan fly ash menyebapkan semakin tinggi luas permukaan partikel dalam satu buah sampel. Sebagai informasi tambahan, penulis dalam melakukan uji serapan air rata-rata ini juga menganalisa beberapa parameter dasar dalam analisa air pada air rendaman pada sampel terpilih. Adapun parameter uji yang adalah uji keasaman (pH), Turbidity dan Conductifity. Hasil analisa kualitas air dari sampel $\mathrm{F}_{4} \mathrm{~B}_{4}$ adalah sebagai berikut :

Tabel 7 Kualitas Air Rendaman Sampel $\mathbf{F}_{4} \mathbf{B}_{4}$.

\begin{tabular}{cccc}
\hline Hari & $\mathbf{p H}$ & Counductivity & Turbidity \\
\hline 1 & 5,66 & 2,04 & 0,38 \\
\hline 2 & 10,64 & 928,20 & 41,22 \\
\hline 3 & 10,61 & 928,23 & 41,25 \\
\hline 4 & 10,60 & 928,56 & 41,26 \\
\hline 5 & 10,57 & 928,67 & 41,28 \\
\hline 6 & 10,58 & 928,72 & 41,28 \\
\hline 7 & 10,58 & 928,74 & 41,29 \\
\hline
\end{tabular}

Berdasarkan data analisa yang diperoleh menunjukkan bahwa produk paving block memiliki $\mathrm{pH}$ yang tinggi. Nalai ini sangat dipengaruhi oleh sifat keasaman perekat yaitu semen. Karena saat dilakukan uji keasaman dari masing-masing bahan, keasaman semen dominan tinggi/basa. Yaitu nilai pada $\mathrm{pH} 10$.

Dilihat dari hasil pengecekan nilai conductivity dan turbidity menunjukkan bahwa ada partikel yang berguguran pada awal perendaman sehingga angka yang diperoleh cukup tinggi. Namun tidak bertambah lagi pada perendaman hari berikutnya. Artinya saat sampel direndam/terkena air hujan, paving block akan larut partikelnya di awal, namun pada hari berikutnya tidak begitu banyak terbawa larut oleh air.

Aplikasi Paving Block

1) Aplikasi Paving Block Berdasarkan Hasil Uji Kuat Tekan

Berdsarkan hasil analisa yang diperoleh dari uji kuat tekan, sampel paving block yang 
terbuat fly ash dan bottom ash memiliki nilai kuat tekan diatas 49,98 MPa sampai 77,27 MPa. Untuk sampel dengan campuran limbah optimum, yaitu sampel $\mathrm{F}_{4} \mathrm{~B}_{4}$ hasil uji kuat tekannya 50,52 $\mathrm{MPa}$.

Sesuai dengan standar kualitas paving block (SNI 03-0691-1996:1), hasil uji kuat tekan menunjujkkan bahwa secara keseluruhan sampel masuk pada standar kelas A, termasuk sampel $\mathrm{F}_{4} \mathrm{~B}_{4}$ yang terdiri dari $20 \%$ perekat dan $80 \%$ limbah. Dengan demikian sampel layak diaplikasikan sebagai bahan kontruksi untuk jalan karena memiliki nilai kuat tekan diatas 40 MPa.

2) Aplikasi Paving Block Berdasarkan Hasil Uji Serapan Air Rata-rata

Berdsarkan hasil analisa yang diperoleh dari uji serapan air rata-rata, sampel paving block yang terbuat fly ash dan bottom ash memiliki nilai serapan air rata-rata diatas 5,06\% sampai $7,52 \%$. Untuk sampel dengan campuran limbah optimum, yaitu sampel $\mathrm{F}_{4} \mathrm{~B}_{4}$ hasil uji kuat tekannya $5,06 \%$.

Sesuai dengan standar kualitas paving block (SNI 03-0691-1996:1), hasil uji kuat tekan menunjujkkan bahwa secara keseluruhan sampel masuk pada standar kelas $B$ dan $C$. Untuk sampel $\mathrm{F}_{4} \mathrm{~B}_{4}, \mathrm{~F}_{2} \mathrm{~B}_{4}, \mathrm{~F}_{4} \mathrm{~B}_{3}, \mathrm{~F}_{2} \mathrm{~B}_{3}, \mathrm{~F}_{1} \mathrm{~B}_{4}, \mathrm{~F}_{1} \mathrm{~B}_{3}, \mathrm{~F}_{4} \mathrm{~B}_{1}, \mathrm{~F}_{2} \mathrm{~B}_{2}, \mathrm{~F}_{3} \mathrm{~B}_{4}$, $\mathrm{F}_{1} \mathrm{~B}_{2}, \mathrm{~F}_{2} \mathrm{~B}_{1}, \mathrm{~F}_{3} \mathrm{~B}_{3}$, dan $\mathrm{F}_{3} \mathrm{~B}_{2}$ termasuk Paving Block kelas $\mathrm{B}$ dan dapat diaplikasikan untuk kebutuhan pembangunan pelataran parkir. Semetara itu untuk sampel $\mathrm{F}_{3} \mathrm{~B}_{1}$ dan $\mathrm{F}_{1} \mathrm{~B}_{1}$ termasuk paving block kelas $\mathrm{C}$ dan dapat diaplikasikan untuk kebutuhan pembangunan trotoar untuk pejalan kaki.

\section{KESIMPULAN}

Setelah dilakukan penelitian pembuatan paving blok berbahan dasar fly ash dan bottom ash sebagai bahan subsitusi agregadnya. Dari penelitian yang telah dilakukan dapat disimpulkan bahwa :

1) Fly Ash dan Bottom Ash dapat dijadikan bahan campuran dalam pembuatan Paving Block sebagai bahan subsitusi agregad pengganti pasir. Campuran maksimum didapatkan pada sampel dengan perbandingan cement, fly ash dan bottom ash adalah $1: 2: 2$. Artinya dalam satu unit produk paving block akan terisolasi $80 \%$ limbah dengan perekat yang berupa cement portland sebanyak $20 \%$.

2) Paving Block yang berbahan fly ash dan bottom ash memiliki nilai kuat tekan yang sangat baik, pada kombinasi campuran perbandingan cement, fly ash dan bottom ash (1: 2 : 2) masih didapatkan nilai kuat tekan sebesar 50,52 MPa. Nilai ini menunjukkan bahwa sampel masuk pada golongan paving block kelas A.

3) Paving Block yang berbahan fly ash dan bottom ash memiliki nilai serapan air rata-rata yang sangat baik, pada kombinasi campuran perbandingan cement, fly ash dan bottom ash (1
: $2: 2)$ masih didapatkan nilai serapan air ratarata sebesar rata 5,06\%. Nilai ini menunjukkan bahwa sampel masuk pada golongan paving block kelas B.

4) Berdasarkan standar yang ditentukan SNI 030691-1996 sampel kombinasi campuran perbandingan cement, fly ash dan bottom ash (1 : 2 : 2) dapat diaplikasikan sebagai bahan kontruksi untuk pembuatan jalan atau pelataran parkir.

\section{PUSTAKA}

Akbar, Muhammad 2009, Kinerja Econimizer pada Boiler. Surabaya : Institut Teknologi Sepuluh November.

Bangunan, P.T.K., 2002. Tata Cara Perencanaan Struktur Beton Untuk Bangunan Gedung SNI 03-2847-2002.

China National Electrical Engineering, 2013. Mine Mouth CFSPP SUMSEL-5 (2x150MW) Vol.6. Ash Handling. China National Electrical Engineering. Co. Ltd.

China National Electric Engineering Company. 2014. Mine Mouth CFSPP SUMSEL-5 : Beijing.

Dyahwanti, Inarni Nur. 2007. Kajian Dampak Lingkungan Kegiatan Penambangan Pasir pada Daerah Sabuk Hijau Gunung Sumbing Daerah Kabupaten Tumanggung. ITS. Surabaya.

Eunike, Filia S P . 2014 . Kuat Tarik Lentur Beton Geopolymer berbasis Abu Terbang (Fly Ash). Universitas Sam Ratulangi. Manado

Faridah, A.M, 2012. Karakteristik Abu Dasar PLTU Paiton: Pengaruh Perlakuan Magnet, $\mathrm{HCl}$ dan Fusi dengan NaOH. Pusat Studi Energi, ITS. Surabaya.

Harris, H., Anam, S., \& Mahmudsyah, S, 2013. Studi pemanfaatan limbah padat dari perkebunan kelapa sawit pada PLTU $6 \mathrm{MW}$ di Bangka Belitung. Jurnal Teknik ITS, Surabaya.

Ismunandar, 2006, Padatan Oksida Logam :Struktur, Sintesis, dan Sifat-sifatnya.

ITB, Bandung.

Kemas AH. 1995. Rancangan Percobaan Teori dan Aplikasi. Raja Grafindo Persada, Jakarta

Kurniawan, F. 2008. Implementasi Sistem Dinamik pada Pengembangan Pola Kemitraan Industri Kecil Dan Menengah Di Dki Jakarta. Industrial and Systems Engineering Assessment Journal (INASEA), 9(2).

Mulyani, S. 2006. Stabilisasi Tanah Lempung Dengan Emnggunakan Abu Terbang Dan Kapur (Doctoral dissertation, Universitas Gadjah Mada).

Munir, Misbachul . 2008 . Pemanfaatan Abu Batubara (fly Ash) untuk Hollow Block yang Bermutu dan Aman bagi Lingkungan. Semarang : Universitas Diponegoro. 
Presiden RI. 1997. Undang Undang No. 32 Tahun 2009 Tentang : Pengelolaan Lingkungan Hidup. Kemmentrian Hukum dan Ham RI : Jakarta.

Sastrosupardi, Adji. 1999. Rancangan Percobaan Praktis Bidang Pertanian, edisi Revisi. Kanisius, Malang.

Sebayang, Surya. 2010. Pengaruh Kdar Abu Terbang sebagai pengganti sejumlah Semen pada Beton Alir Mutu Tinggi. Bandar Lampung :Universitas Lampung.

SNI-03-0691-1996, Persyaratan mutu bata beton (paving block),. Badan Standarisasi Nasional, Jakarta.

Suseno, Hendro. 2012 . Pengaruh Penggunaan Bottom Ash Sebagai Pengganti Tanah Liat pada Campuran Bata Terhadap Kuat Tekan Bata. Universitas Brawijaya, Malang.

Yusuf, Yulizar .2013. Pengaruh Penambahan Abu Terbang (Fly Ash) Terhadap Kuat Tekan Mortar Semen Tipe PCC Serta Analisis Air Laut Yang Digunakan Untuk Perendaman. Jurusan Kimia, Fakultas MIPA, Universitas Andalas : Padang.

Zakaria, 2003, Analisis Kandungan Mineral Magnetik pada Batuan Beku dari Daerah Istemewa Yogyakarta dengan Metode X-Ray Diffraction, skripsi, Fakultas Keguruan dan Ilmu Pendidikan, Universitas Halouleo, Kendari. 
ISSN: 2085-0859

HALAMAN INI SENGAJA DI KOSONGI 